\title{
Evaluation of Fungicides against Fusarium oxysporum f.sp. lycopersici the Cause of Fusarium Wilt of Tomato
}

\author{
Salman Ahmad ${ }^{*}$, Maryam Yousaf ${ }^{1}$, Romana Anjum² ${ }^{2}$, Waqas Raza', Yasir Ali ${ }^{3}$, Malik Abdul Rehman ${ }^{4}$ \\ ${ }^{1}$ Department of Plant Pathology, College of Agriculture, University of Sargodha, Sargodha, Pakistan. \\ ${ }^{2}$ Department of Plant Pathology, University of Agriculture, Faisalabad, Pakistan. \\ ${ }^{3}$ College of Agriculture, Bahauddin Zakariya University. Bahadur Sub-campus, Layyah, Pakistan. \\ ${ }^{4}$ Citrus Research Institute, Sargodha, Punjab, Pakistan.
}

\section{A R T I C L E I N F O}

\section{Article History}

Received: September 13, 2021

Revised: December 11, 2021

Accepted: December 26, 2021

\section{Keywords}

Vegetables

Disease

Chemicals

Laboratory

Chemical control

\section{A B S T R A C T}

Tomato is very significant and full of nutrition vegetable crop. It is enriched with vitamin a and C, lycopene, and protects from prostate cancer, cardiovascular diseases. Tomato wilt disease (TWD) caused by F. oxysporum f.sp. lycopersici (Fol) is a serious threat to tomato crop in Pakistan and spreading to those areas in which it was not previously present. The current research was planned to evaluate the fungi-toxic activity of fungicides against $F$. oxysporum in vitro and under greenhouse conditions. Four fungicides which include Carbendazim, Benomyl, Curzate and Nativo, at 500ppm, $750 \mathrm{ppm}$ and $1000 \mathrm{ppm}$ concentrations, were evaluated using food poison technique. The overall results showed that all fungicides significantly $(\mathrm{P}<0.05)$ inhibited mycelial growth of $F$. oxysporum, however, Nativo proved to be best followed by Carbendazim, Benomyl at all concentrations. The reduction in colony growth of pathogen gradually increased by increasing the fungicide concentration. Two fungicides, Nativo and Carbendazim and their concentrations 750 and $1000 \mathrm{ppm}$, which proved to be effective in laboratory conditions, also evaluated under greenhouse conditions. Both fungicides effectively controlled TWD under greenhouse conditions. The present research revealed that Nativo and Carbendazim at 750 and $1000 \mathrm{ppm}$ concentrations are effective against Fol, thus may be included in management strategy of TWD.

Corresponding Author: Salman Ahmad

Email: salman.ahmad@uos.edu.pk

(C) The Author(s) 2021.

\section{INTRODUCTION}

Tomato (Lycopersicon esculentum L.) is among the world's most widely farmed and consumed vegetable crops, and it is thought to be the world's second most important vegetable after potato (Saeed et al., 2014). Tomatoes are being consumed as fresh fruit and salad, as well as several other products, such as tomato juice, tomato sauce, soup, and even a variety of other foods, are also made from tomatoes (Alam et al., 2007: Bhowmik et al., 2012). It is grown in 145 countries including Turkey, China, India, United States, and Egypt which are the major tomato-producing countries in the global economy It is farmed on 58.4 thousand hectares in Pakistan, yielding 0.55 million tonnes / ha per year (FAOSTAT, 2019). Sindh province is leading tomato-producing area in Pakistan, with an annual production of 153.3 thousand tons and a yield per hectare is 7.3 thousand tons. Tandojam is one of Pakistan's most important tomato-producing districts. Every year, it yields many tons of tomatoes (Nizamani et al., 2012). In comparison to other tomato-growing countries, this average yield is poor. The United States is the leading producer of tomato with 96.80 tons per 
hectare yield, followed by China, Egypt, India, and Pakistan 59.25 t/ha, 40.96 t/ha, 24.65 t/ha, and 9.44 t/ha respectively (GOP, 2018). At distinct essential development phases from sowing to maturity, the tomato crop is extremely vulnerable to different biotic and abiotic diseases.

Adaptability in relation to different habitats and high nutritive value has made tomato more popular in recent years. Various factors are responsible for low yield and among them diseases are of most concern. Tomato crop is prone to different fungal, bacterial, nematode and viral diseases. Among the fungal diseases, tomato wilt is the worst and caused large destruction in terms of both quality and quantity the causal organism of tomato wilt is Fusarium oxysporum, which attacks roots and causes production losses of 30 to $40 \%$, in some cases losses reaching $90 \%$ (Nirmaladev et al., 2016). Fusarium wilt disease of tomato is a most important vascular disease of tomato worldwide. The soil-borne pathogen Fusarium spp. infects a wide range of hosts. The disease is characterized by the falling, discoloration, wilting, and death of lower leaves (Akrami et al., 2015). The aerial mycelia of Fusariumoxysporum are round and white at first, then turn to pale pink (Nizamani et al., 2020).

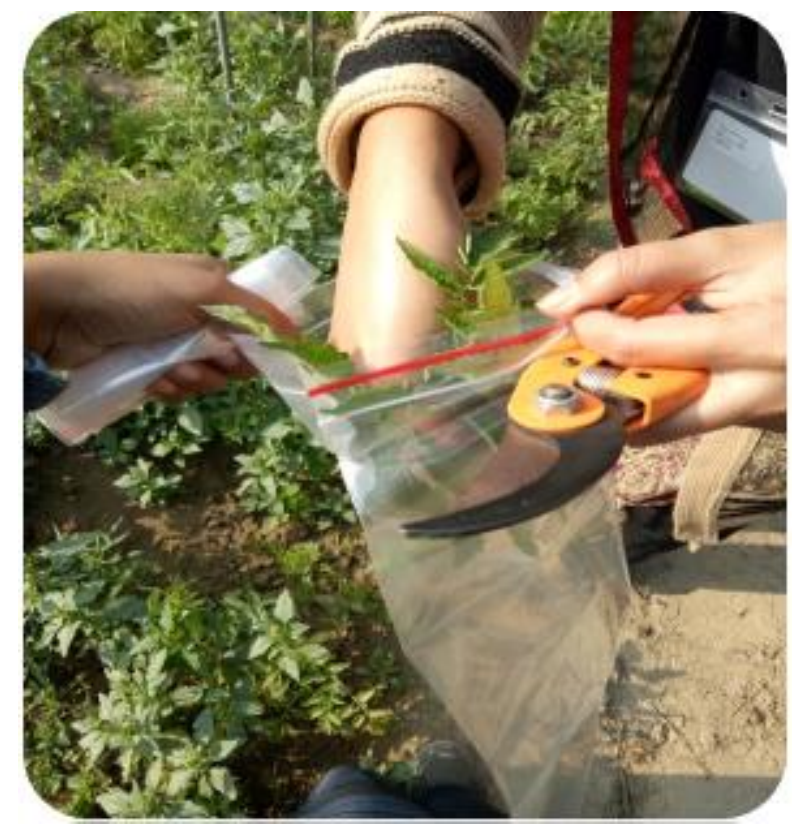

Figure 1. Collection of samples on the basis of symptoms.

After the surveys, isolation of $F$. oxysporum fungus from diseased plants was carried out. Samples were cut into pieces of $1-\mathrm{cm}^{2}$ containing both diseased and healthy portions (Nishimura, 2007). Samples were washed in
During the last few years, it has been noticed that fusarium wilt found most abundantly in tomato growing areas due to favorable environmental conditions and currently its management is being managed excellently with the use of different fungicides (Zhang et al., 2003; Verma et al., 2010). As inappropriate use of chemicals leads to serious human health hazards, therefore, proper concentration of fungicides at proper intervals could be helpful diminishing down deadly effects of fungicides (Kankwatsa et al., 2003; Kirk et al., 2005; Ghazanfar et al., 2016). The main objective of this study was to evaluate the in vitro and greenhouse efficacy of different fungicides with different concentrations against fusarium wilt of tomato.

\section{METHODS AND MATERIAL}

Surveys of most tomato wilt affected districts of Province Punjab including Hafizabad, Pakpattan, Khushab, Sargodha and Faisalabad, Pakistan, was conducted in 2018-19. Samples were collected from diseased tomato plants with typical symptoms and were placed in polythene zipper bags separately, labelled properly and stored in an ice box prior to isolations (Figure 1).

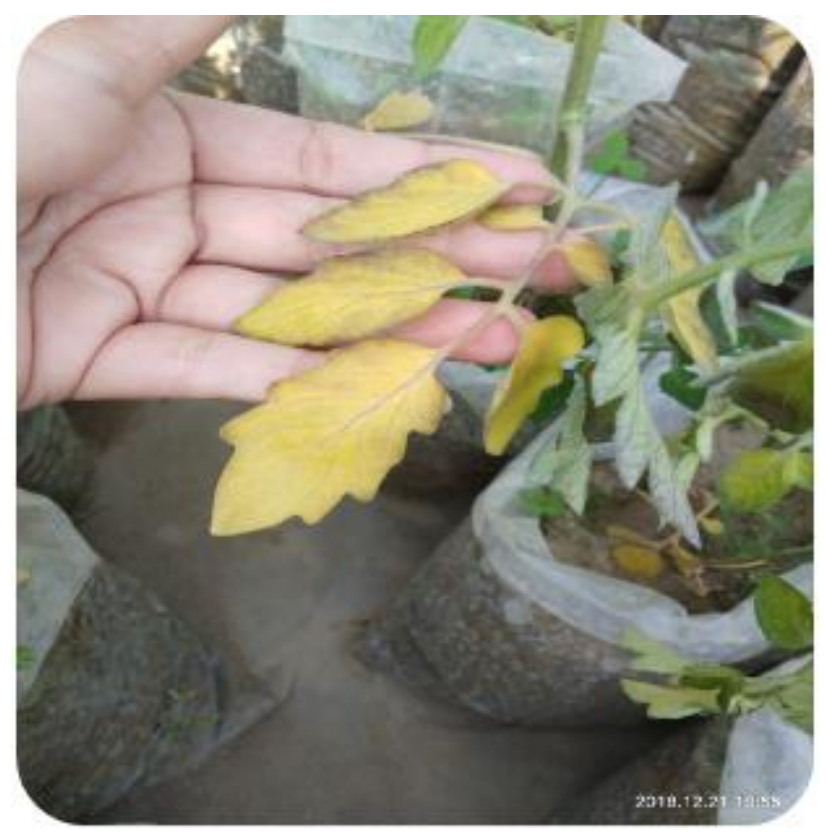

$75 \%$ ethanol for $30 \mathrm{~s}, 0.5 \% \mathrm{NaOCl}$ for $1 \mathrm{~min}$ as well as rinsed with sterilized double distilled water (Ignjatov et al., 2012). These washed samples were placed in petri-plates having commercial potato dextrose agar 
medium (Product No. 70139-500G, Merck, Germany) (Machado et al., 2002; Mathur and Kongsdal, 2003). PDA media petri-plates having leaf samples were placed in incubator at $\pm 25^{\circ} \mathrm{C}$ in dark for seven days. The isolates were then shifted to a thermostat with UV light and having $25^{\circ} \mathrm{C}$ temperature, for ten days

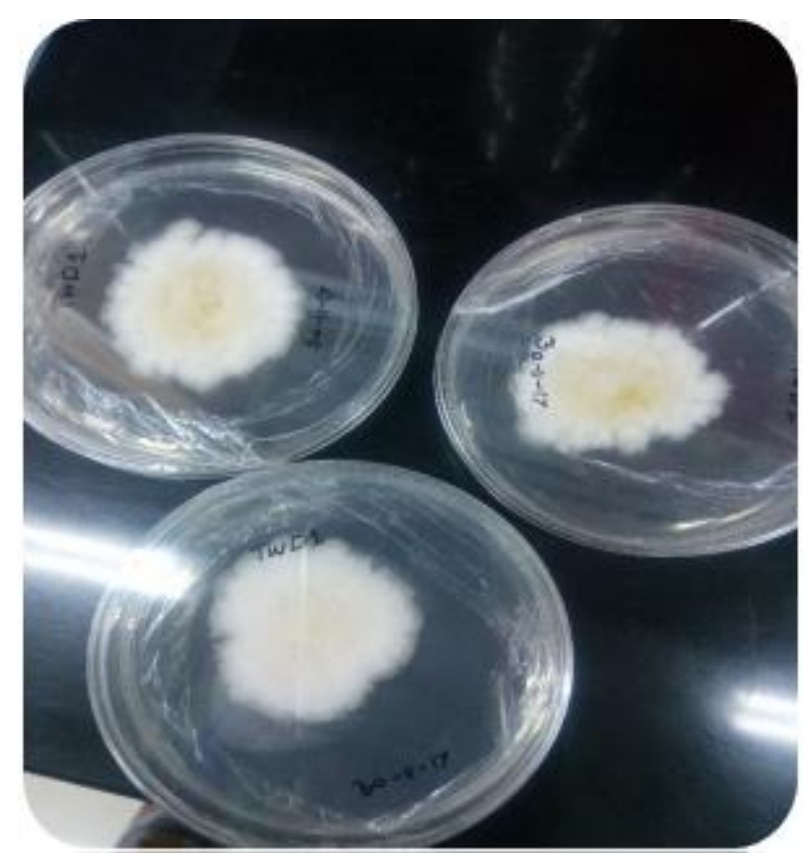

(Burgess et al., 1994). This was done to induce pigmentation and sporulation in culture. The cultures were purified using single spore technique (Choi et al., 1999). First on the basis of symptomology and then on conidial characteristics of the fungus, was identified as F. oxysporum (Figure 2).

Figure 2. Characteristics of the fungus identified as F. oxysporum under microscope.

\section{Evaluation of systemic fungicides against TWD in Laboratory Conditions}

Efficacy of different systemic fungicides, Crabendazim, Curzate, Nativo and Benomyl, with the concentration of $500 \mathrm{ppm}, 750 \mathrm{ppm}$ and $1000 \mathrm{ppm}$, was evaluated in vitro conditions against the selected isolates of TWD by poisoned food technique ( $\mathrm{Mj}$ et al., 2017). For this, fungicides solutions were prepared and then added in the

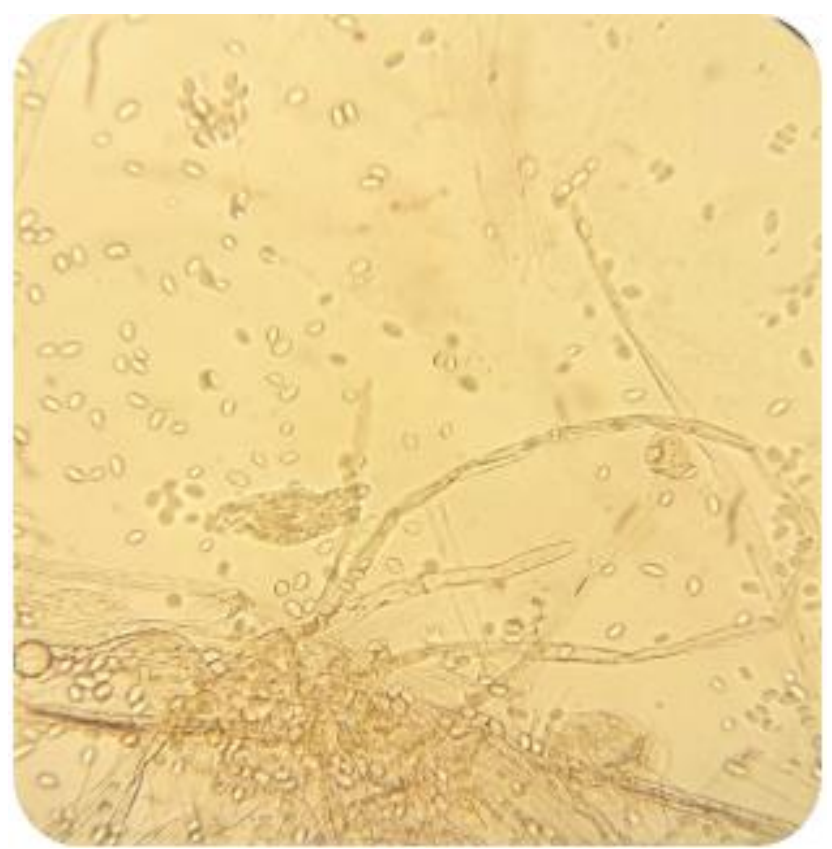

molten PDA media, and then the media was allowed to solidify in the petri-plates. Then, mycelial plugs of isolates of TWD were placed in the center of poisoned media plates and control plates. In control plates, fungicides solutions were not added. The rate of mycelial growth was recorded, and percent inhibition of mycelia growth over control was calculated using the following formula (Vincet, 1947).

$$
\% \text { Inhibition }=\frac{\text { Radial growth in control }- \text { Radial growth in treatment }}{\text { Radial growth in control }} \times 100
$$

\section{Evaluation of systemic fungicides against the selected isolates of TWD under greenhouse conditions}

On the basis of in vitro results, further experiments were conducted to check the effectiveness of fungicides under greenhouse conditions. The concentrations found best in vitro were used in greenhouse experiments and the fungicides were applied alone and in combinations. Tomato plants were inoculated with 1 x 109 conidia/mL by drenching method after transplanting seedlings in greenhouse pots (Basco et al., 2017). Three treatments were applied by the soil drenching method in such a way that first application of treatments was applied before inoculation of $F$. oxysporum, second treatment application was applied after one week of inoculation and third treatment application was applied after three weeks of inoculation. Disease development data was noted 7 times on weekly basis while percent disease incidence data was recorded using following formula (Lievens et al., 2009). 


$$
\text { DSI } \%=\frac{[\text { sum }(\text { class frequency } \times \text { score of rating class })]}{[(\text { total number of plants }) \times(\text { maximal disease index })]} \times 100
$$

\section{Statistical Analysis}

Recorded data was subjected to statistical analysis by using R-software. Lease significant test was used to determine the most significant treatments (Fisher, 1948).

\section{RESULTS}

\section{Evaluation of Fungicides}

The effect of four different fungicides, carbendazim (Bavistin $50 \% \mathrm{WP}$ ), benomyl (Benlate $50 \% \mathrm{WP}$ ), Curzate (Cymoxanil $60 \%$ ) and Nativo (Tebuconazole $50 \%+$ Trifloxystrobin $25 \%$ ), at concentrations of 500, 750, and $1000 \mathrm{ppm}$, respectively, were evaluated in vitro against the growth of three isolates of Fol on PDA.

Efficacy of fungicides against isolates TWD-20, TWD25 and TWD-28 of Fol

All fungicides significantly $(\mathrm{P}<0.05)$ inhibited mycelial growth of isolate 20 of Fol in-vitro. Nativo showed significantly $(\mathrm{P}<0.05)$ higher mycelial inhibition at all concentrations at $3^{\text {rd }}, 6^{\text {th }}$ and $9^{\text {th }}$ day of colony growth followed by Carbendazim, Benomyl and Curzate (Figure 3). All fungicides showed significantly higher mycelial growth inhibition at $9^{\text {th }}$ day of growth while significantly less at $3^{\text {rd }}$ day of growth. At $6^{\text {th }}$ and $9^{\text {th }}$ day of growth, with the increase of fungicidal concentration from $750 \mathrm{ppm}$ to $1000 \mathrm{ppm}$, growth inhibition increased, however, at $3^{\text {rd }}$ day of growth, growth inhibition decreased with the increase of fungicidal concentration (Figure 3). All fungicides significantly $(\mathrm{P}<0.05)$ inhibited mycelial growth of isolate 25 of Fol in-vitro. Nativo showed significantly $(\mathrm{P}<0.05)$ higher mycelial inhibition at all concentrations at $6^{\text {th }}$ and $9^{\text {th }}$ day of colony growth followed by Carbendazim, Benomyl and Curzate (Figure $3)$. At $3^{\text {rd }}$ day of growth, the inhibitory effect of Nativo and Benomyl was same while Carbendazim was second effective. Curzate was significantly less effective at $3^{\text {rd }}$ day of growth. All fungicides showed significantly higher mycelial growth inhibition at $9^{\text {th }}$ day of growth while significantly less at $3^{\text {rd }}$ day of growth. At $3^{\text {rd }}, 6^{\text {th }}$ and $9^{\text {th }}$ day of growth, with the increase of fungicidal concentration from $500 \mathrm{pm}$ to $1000 \mathrm{ppm}$, growth inhibition also increased (Figure 4). All fungicides significantly $(\mathrm{P}<0.05)$ inhibited mycelial growth of isolate 28 of Folin vitro. Nativo showed significantly $(\mathrm{P}<$ 0.05 ) higher mycelial inhibition at all concentrations at $3^{\text {rd }}, 6^{\text {th }}$ and $9^{\text {th }}$ day of colony growth followed by Carbendazim, Benomyl and Curzate (Figure 5). At $3^{\text {rd }}$ day of growth, the inhibitory effect of Benomyl and Curzate was same at $500 \mathrm{ppm}$; however, was different at $750 \mathrm{ppm}$ and $1000 \mathrm{ppm}$. Curzate was significantly less effective at $3^{\text {rd }}, 6^{\text {th }}$ and $9^{\text {th }}$ day of growth at all concentrations. All fungicides showed significantly higher mycelial growth inhibition at $9^{\text {th }}$ day of growth while significantly less at $3^{\text {rd }}$ day of growth. At $3^{\text {rd }}, 6^{\text {th }}$ and $9^{\text {th }}$ day of growth, with the increase of fungicidal concentration from $500 \mathrm{pm}$ to $1000 \mathrm{ppm}$, growth inhibition also increased (Figure 5).

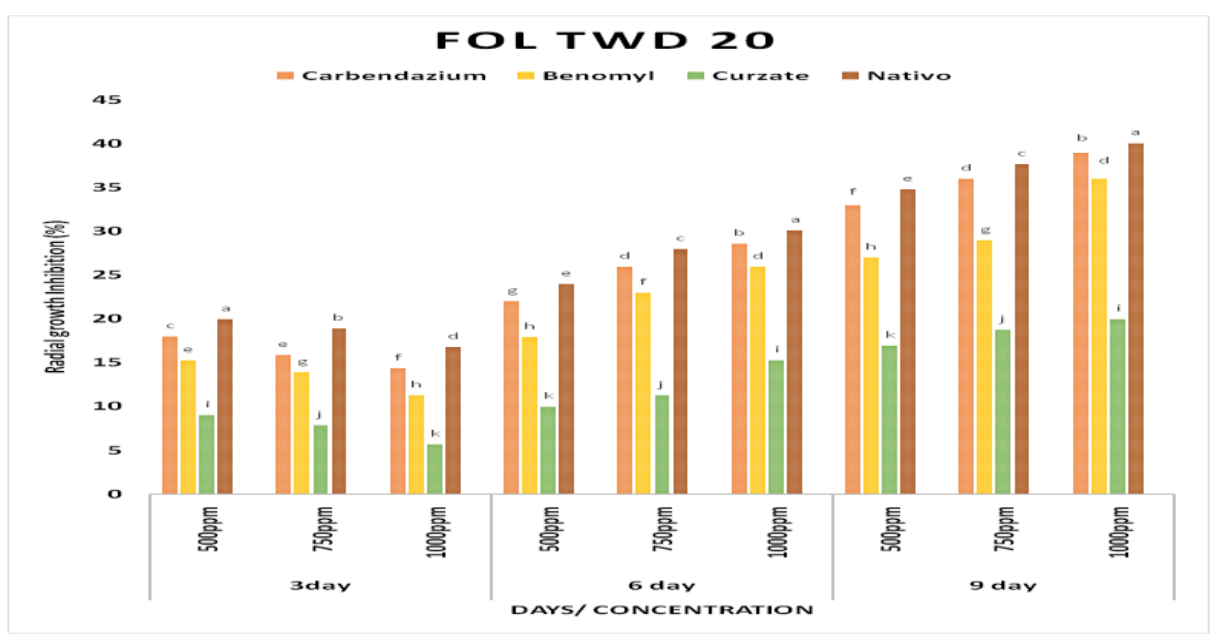

Figure 3. Effect of four fungicides at three different concentrations on mycelial growth of isolate TWD-20 of Folin vitro at 3rd, 6th and 9th day of colony growth. 


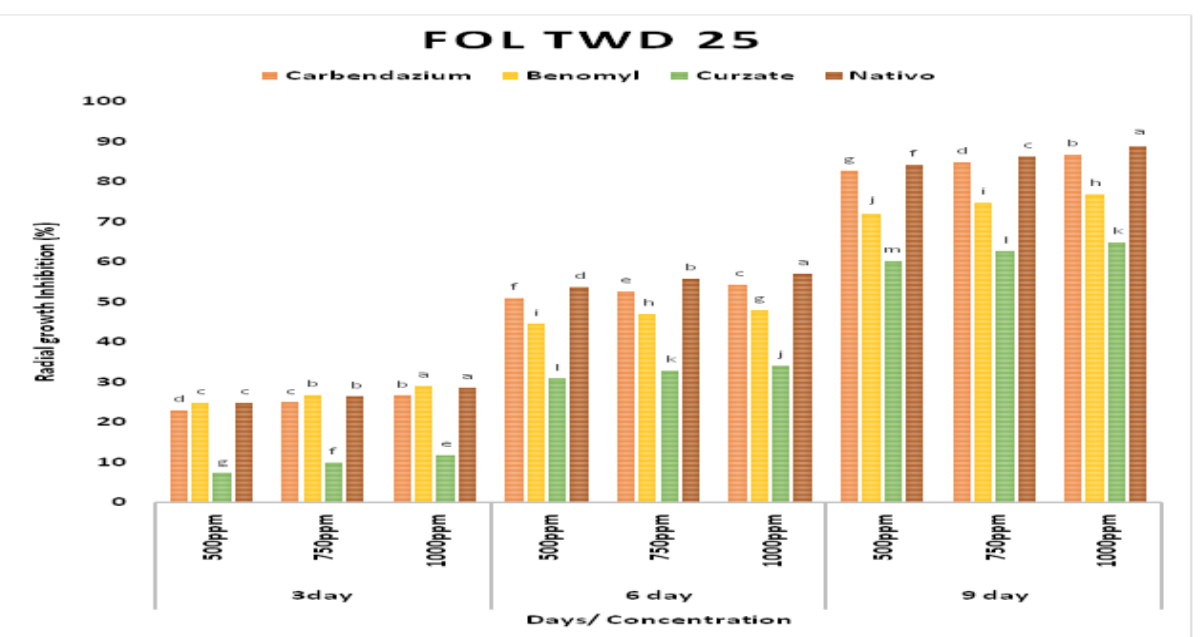

Figure 4. Effect of four fungicides at three different concentrations on mycelial growth of isolate TWD-25 of Folin vitro at $3^{\text {rd }}, 6^{\text {th }}$ and $9^{\text {th }}$ day of colony growth.

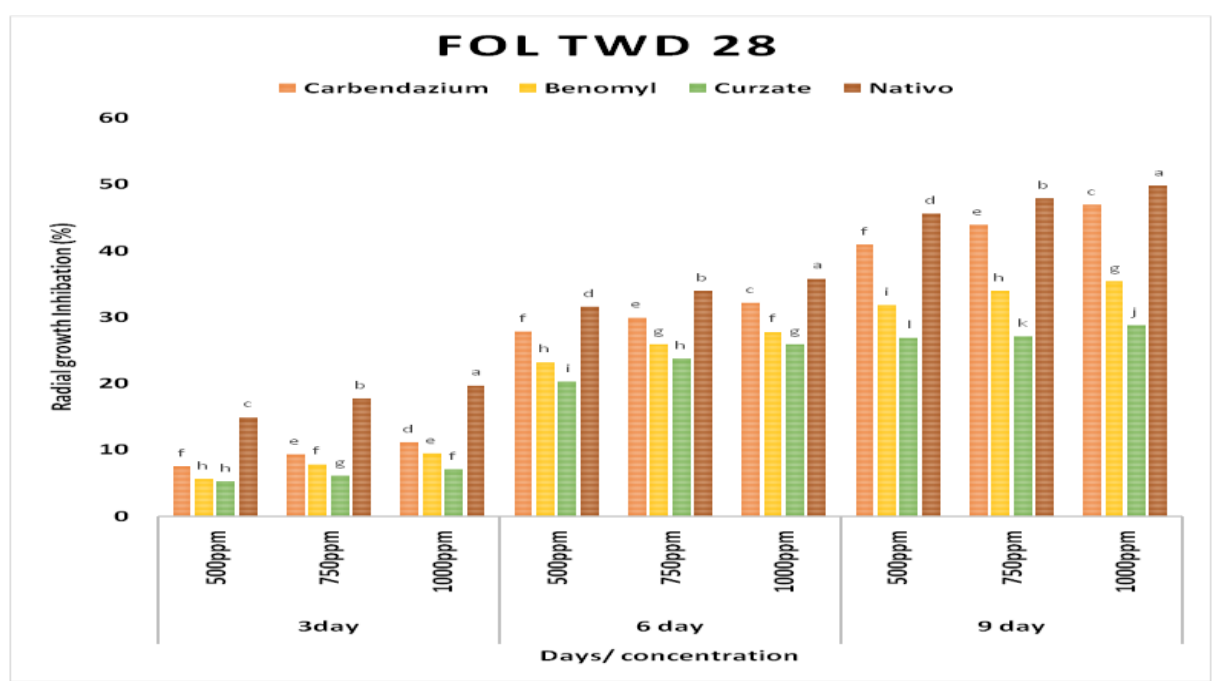

Figure 5. Effect of four fungicides at three different concentrations on mycelial growth of isolate TWD-28 of Folin vitro at $3^{\text {rd }} 6^{\text {th }}$ and $9^{\text {th }}$ day of colony growth.

Efficacy of fungicides against isolates TWD-20, TWD25, TWD-28, TWD-31, TWD-33 and TWD-39 of Fol under greenhouse conditions

Two fungicides, Nativo and Carbendazim, and two concentrations $750 \mathrm{ppm}$ and $1000 \mathrm{ppm}$, which were found effective in vitro, were evaluated under greenhouse conditions against five isolates. Nativo significantly ( $\mathrm{P}<$ 0.05 ) controlled higher disease severity of TWD caused by isolate TWD-20 compared to Carbendazim and control (Figure 6). Nativo significantly controlled more disease severity at $750 \mathrm{ppm}$ compared to $1000 \mathrm{ppm}$ concentration and control. Similarly, Carbendazim also significantly $(\mathrm{P}<0.05)$ controlled more disease severity at $750 \mathrm{ppm}$ than $1000 \mathrm{ppm}$ and control (Figure 6). After $1^{\text {st }}, 2^{\text {nd }}, 3^{\text {rd }}, 4^{\text {th }}, 5^{\text {th }}, 6^{\text {th }}$ and $7^{\text {th }}$ week of inoculation of isolate TWD-20, Nativo treated plants showed disease severity 11 and $9 \%, 32$ and $20 \%, 50$ and $38 \%, 59$ and $41 \%, 69$ and $41 \%, 76$ and $56 \%$, and 69 and $45 \%$, at $750 \mathrm{ppm}$ and $1000 \mathrm{ppm}$, respectively, compared to control $(40,50,60$, $70,80,90$ and $100 \%$, respectively). Similarly, after $1^{\text {st, }} 2^{\text {nd }}$, $3^{\text {rd }} 4^{\text {th }}, 5^{\text {th }}, 6^{\text {th }}$ and $7^{\text {th }}$ week of inoculation of isolate TWD20, Carbendazim treated plants showed disease severity 20 and $18 \%, 36$ and $23 \%, 53$ and $41 \%, 62$ and $46 \%, 75$ and $51 \%, 84$ and $61 \%$, and 86 and $60 \%$, at $750 \mathrm{ppm}$ and $1000 \mathrm{ppm}$, respectively, compared to control $(40,50,60$, 70, 80, 90, 100), respectively) (Figure 6). 


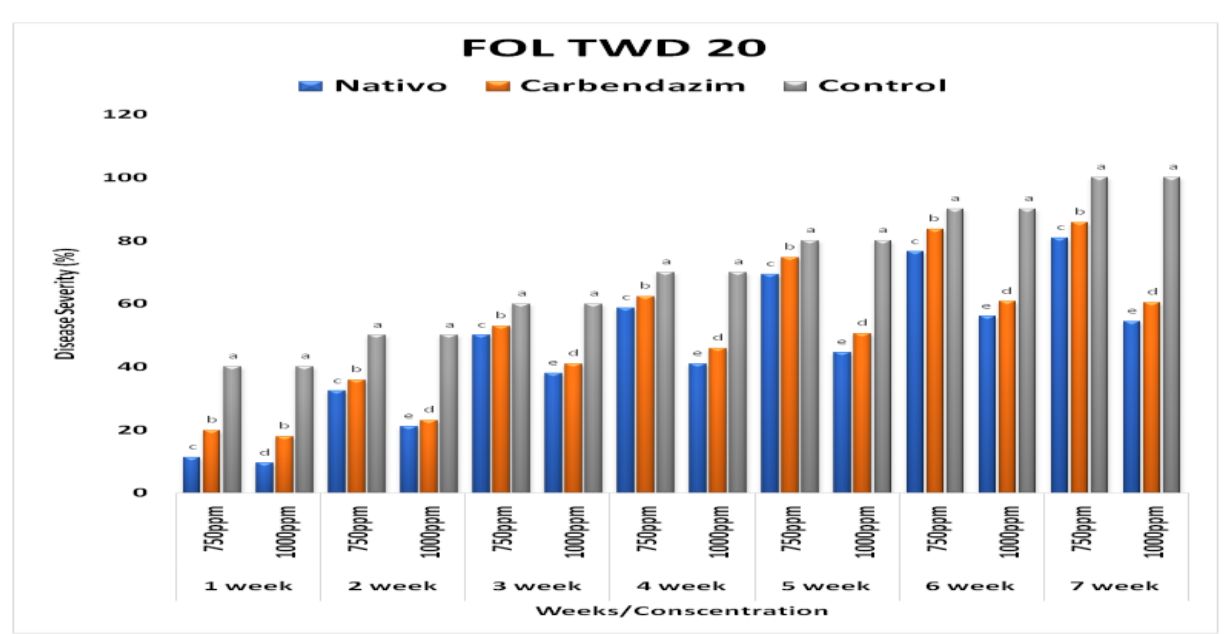

Figure 6. Effect of Nativo and Carbendazim on disease severity of isolate TWD-20 of Fol at 750 and 1000ppm concentrations under greenhouse conditions for the period of seven weeks.

Nativo significantly $(\mathrm{P}<0.05)$ controlled higher disease severity of TWD caused by isolate TWD-25 compared to Carbendazim and control (Figure 6). Nativo significantly controlled more disease severity at $750 \mathrm{ppm}$ compared to 1000 ppm concentration and control. Similarly, Carbendazim also significantly $(\mathrm{P}<0.05)$ controlled more disease severity at $750 \mathrm{ppm}$ than $1000 \mathrm{ppm}$ and control (Figure 7). After $1^{\text {st }}, 2^{\text {nd }}, 3^{\text {rd }}, 4^{\text {th }}, 5^{\text {th }}, 6^{\text {th }}$ and $7^{\text {th }}$ week of inoculation of isolate TWD-25, Nativo treated plants showed disease severity 25 and $20 \%, 35$ and $31 \%, 42$ and
$41 \%, 52$ and $51 \%, 63$ and $61 \%, 73$ and $71 \%$, and 85 and $81 \%$, at $750 \mathrm{ppm}$ and $1000 \mathrm{ppm}$, respectively, compared to control (40,50, 60, 70, 80, 90 and 100\%, respectively). Similarly, after $1^{\text {st }}, 2^{\text {nd }}, 3^{\text {rd }}, 4^{\text {th }}, 5^{\text {th }}, 6^{\text {th }}$ and $7^{\text {th }}$ week of inoculation of isolate TWD-25, Carbendazim treated plants showed disease severity 29 and $24 \%, 39$ and 35 $\%, 47$ and $45 \%, 57$ and $55 \%, 66$ and 65\%, 76 and $74 \%$, and 89 and $84 \%$, at $750 \mathrm{ppm}$ and $1000 \mathrm{ppm}$, respectively, compared to control $(40,50,60,70,80,90,100 \%$, respectively) (Figure 7).

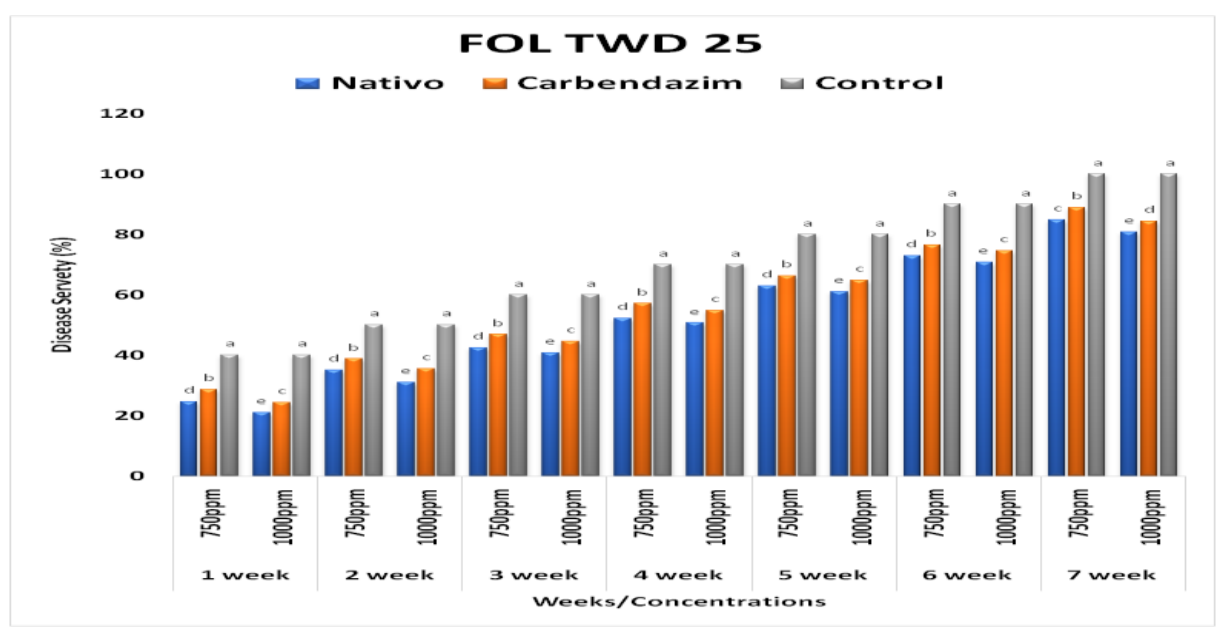

Figure 7. Effect of Nativo and Carbendazim on disease severity of isolate TWD-25 of Folat 750 and 1000ppm concentrations under greenhouse conditions for seven weeks.

Nativo significantly $(\mathrm{P}<0.05)$ controlled higher disease severity of TWD caused by isolate TWD-28 compared to Carbendazim and control (Figure 8). Nativo significantly controlled more disease severity at 750 ppm while, carbendazim also significantly $(\mathrm{P}<0.05)$ prohibited more disease severity at $750 \mathrm{ppm}$ than $1000 \mathrm{ppm}$ and control. After isolate inoculation TWD-28, Nativo treated plants showed disease severity 13 and $10 \%, 20$ and $18 \%, 28$ and $25 \%, 37$ and $30 \%, 45$ and $35 \%, 50$ and $40 \%$, and 60 and $48 \%$, at 750 and $1000 \mathrm{ppm}$, 
respectively, compared to control $(20,30,40,50,60,70$, 80 , respectively). Similarly, after $1^{\text {st }}, 2^{\text {nd }}, 3^{\text {rd }}, 4^{\text {th }}, 5^{\text {th }}, 6^{\text {th }}$ and $7^{\text {th }}$ week of inoculation of isolate TWD-28, Carbendazim treated plants showed disease severity 18 and $15 \%, 25$ and $23 \%, 35$ and $29 \%, 43$ and $35 \%, 50$ and $37 \%$, 55 and $45 \%$, and 65 and $53 \%$, at 750 and $1000 \mathrm{ppm}$, respectively, compared to control $(20,30,40$, $50,60,70,80$, respectively (Figure 8).

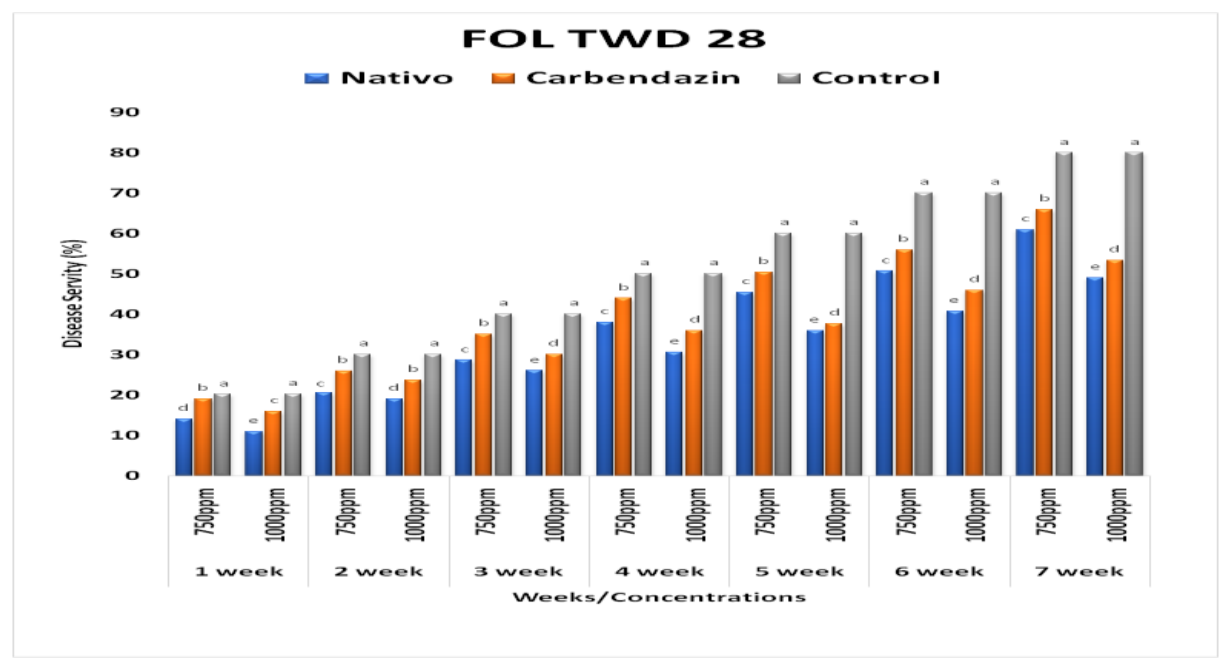

Figure 8. Effect of Nativo and Carbendazim on disease severity of isolate TWD-28 of Folat 750 and 1000ppm concentrations under greenhouse conditions for seven weeks.

Nativo significantly $(\mathrm{P}<0.05)$ controlled higher disease severity of TWD caused by isolate TWD-31 compared to Carbendazim and control (Figure 9). Nativo significantly controlled more disease severity at $750 \mathrm{ppm}$ compared to 1000 ppm concentration and control. Similarly, chemical, carbendazim considerably controlled more disease severity at $750 \mathrm{ppm}$ than $1000 \mathrm{ppm}$ conc. (Figure 8). After $1^{\text {st }}, 2^{\text {nd, }}$ $3^{\text {rd }}, 4^{\text {th }}, 5^{\text {th }}, 6^{\text {th }}$ and $7^{\text {th }}$ week of inoculation of isolate TWD-31, Nativo treated plants showed disease severity 0.1 and $1 \%$,
5 and $0.8 \%, 7$ and $1 \%, 10$ and $2 \%, 13$ and $2 \%, 18$ and $3 \%$, and 23 and $4 \%$, at 750 and 1000 ppm, respectively, compared to control $(5,10,15,20,25,30$ and $35 \%$, respectively). Similarly, after $1^{\text {st }}, 2^{\text {nd }}, 3^{\text {rd }}, 4^{\text {th }}, 5^{\text {th }}, 6^{\text {th }}$ and $7^{\text {th }}$ week of inoculation of isolate TWD-31, Carbendazim treated plants showed disease severity 3 and $1 \%, 7$ and $1 \%, 8$ and $2 \%, 11$ and $3 \%, 18$ and $4 \%, 21$ and $5 \%$, and 25 and $6 \%$, at 750 and $1000 \mathrm{ppm}$, respectively, compared to control $(5,10$, $15,20,25,30$ and $35 \%$, respectively) (Figure 9).

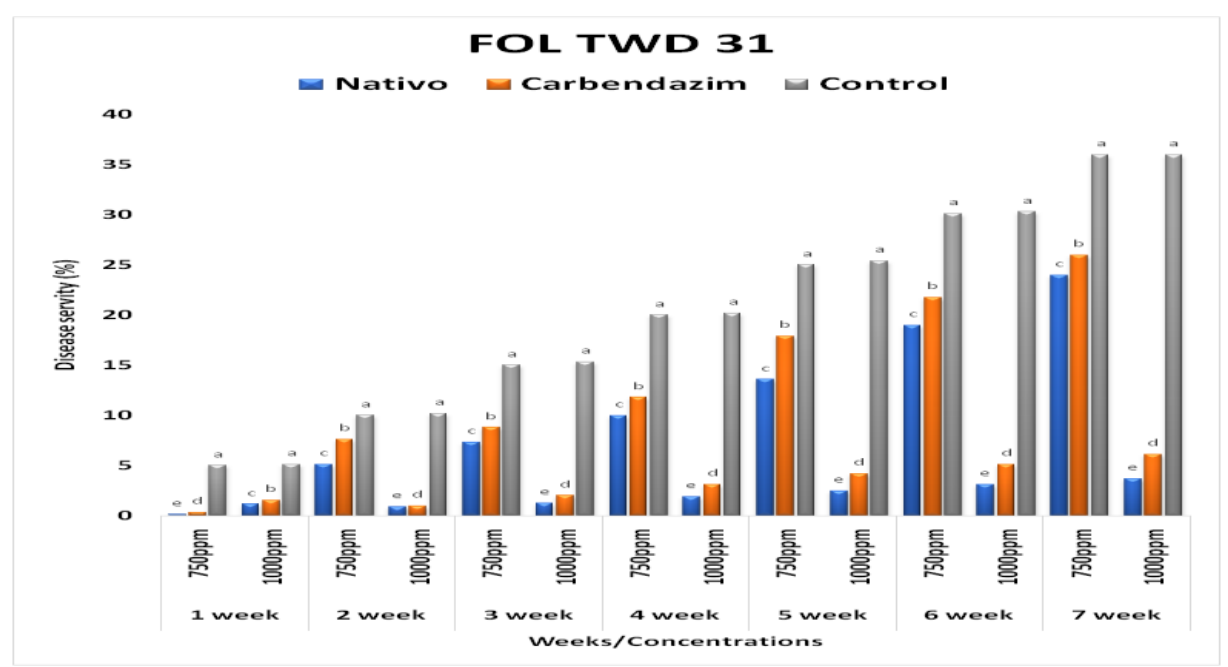

Figure 9. Effect of Nativo and Carbendazim on disease severity of isolate TWD-31 of Folat 750 and $1000 \mathrm{ppm}$ concentrations under greenhouse conditions for seven weeks. 
Nativo significantly $(\mathrm{P}<0.05)$ controlled higher disease severity of TWD caused by isolate TWD-33 compared to Carbendazim and control. Nativo significantly controlled more disease severity at $1000 \mathrm{ppm}$ compared to $750 \mathrm{ppm}$ concentration and control. Similarly, Carbendazim also significantly $(\mathrm{P}<0.05)$ restricted more disease severity at $1000 \mathrm{ppm}$ than $750 \mathrm{ppm}$ and control (Figure 10 ). After $1^{\text {st }}, 2^{\text {nd }}, 3^{\text {rd }}, 4^{\text {th }}, 5^{\text {th }}, 6^{\text {th }}$ and $7^{\text {th }}$ week of inoculation of isolate TWD-33, Nativo treated plants showed disease severity 14 and $11 \%, 23$ and $21 \%, 30$ and $28 \%, 41$ and $33 \%, 48$ and $41 \%, 56$ and $47 \%$, and 65 and $49 \%$, at 750 and 1000 ppm, respectively, compared to control $(20,30,40,50,60,70$ and $80 \%$, respectively). Similarly, after $1^{\text {st }}, 2^{\text {nd }}, 3^{\text {rd }}, 4^{\text {th }}, 5^{\text {th }}, 6^{\text {th }}$ and $7^{\text {th }}$ week of inoculation of isolate TWD-33, Carbendazim treated plants showed disease severity 19 and $16 \%, 28$ and $26 \%, 30$ and $33 \%, 46$ and $39 \%, 53$ and $46 \%, 61$ and $52 \%$, and 70 and $55 \%$, at 750 and $1000 \mathrm{ppm}$, respectively, compared to control $(20,30,40,50,60,70$ and $80 \%$, respectively) (Figure 10).

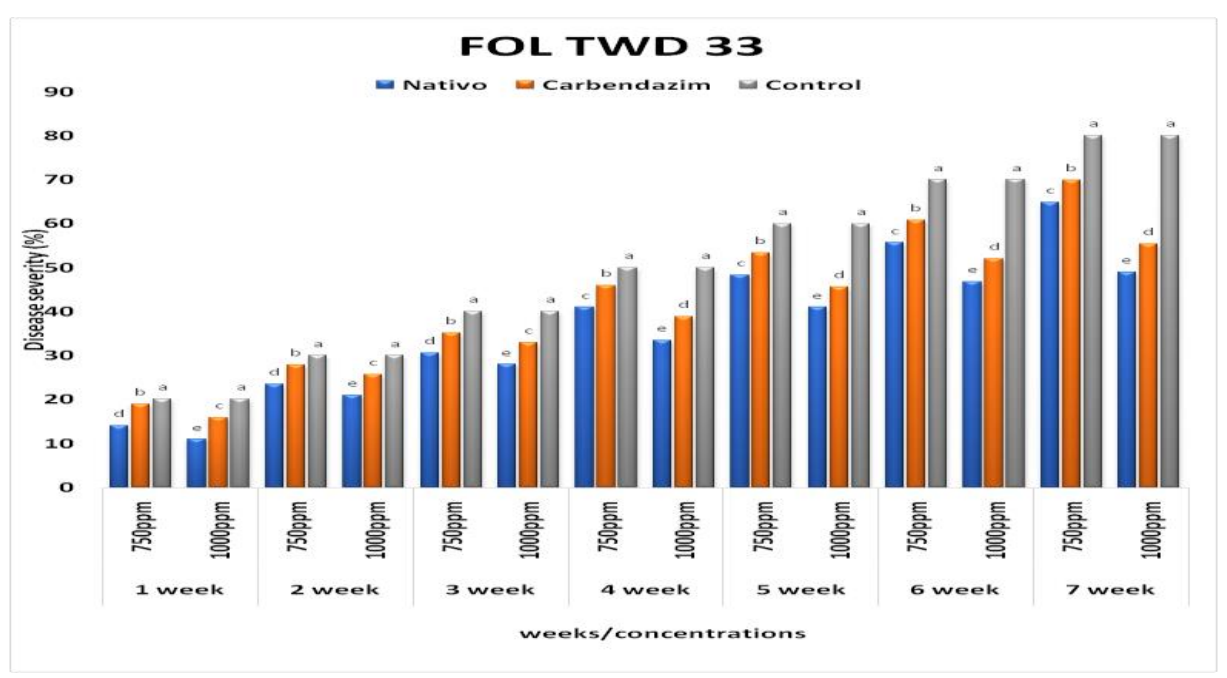

Figure 10. Effect of Nativo and Carbendazim on disease severity of isolate TWD-33 of Fol at 750 and 1000ppm concentration under greenhouse conditions for the period of seven weeks.

Nativo significantly $(\mathrm{P}<0.05)$ controlled higher disease severity of TWD caused by isolate TWD-39 compared to carbendazim and control. Nativo significantly controlled more disease severity at $1000 \mathrm{ppm}$ compared to 750 ppm concentration and control. Similarly, Carbendazim also significantly $(\mathrm{P}<0.05)$ controlled more disease severity at $1000 \mathrm{ppm}$ than $750 \mathrm{ppm}$ and control (Figure 11). After $1^{\text {st }}, 2^{\text {nd }}, 3^{\text {rd }}, 4^{\text {th }}, 5^{\text {th }}, 6^{\text {th }}$ and $7^{\text {th }}$ week of inoculation of isolate TWD-39, Nativo treated plants showed disease severity 25 and $19 \%, 33$ and $26 \%, 40$ and $33 \%, 52$ and $40 \%, 63$ and $51 \%, 71$ and $69 \%$, and 82 and $81 \%$, at 750 and 1000 ppm, respectively, compared to control $(40,50,60,70,80,90$ and $100 \%$, respectively). Similarly, after $1^{\text {st }}, 2^{\text {nd }}, 3^{\text {rd }}, 4^{\text {th }}, 5^{\text {th }}, 6^{\text {th }}$ and $7^{\text {th }}$ week of inoculation of isolate TWD-39, Carbendazim treated plants showed disease severity 29 and $22 \%, 38$ and $30 \%, 47$ and $38 \%, 57$ and $49 \%, 66$ and $58 \%, 76$ and $74 \%$, and 89 and $86 \%$, at 750 and $1000 \mathrm{ppm}$, respectively, compared to control $(40,50,60,70,80,90$ and $100 \%$, respectively) (Figure 11). 


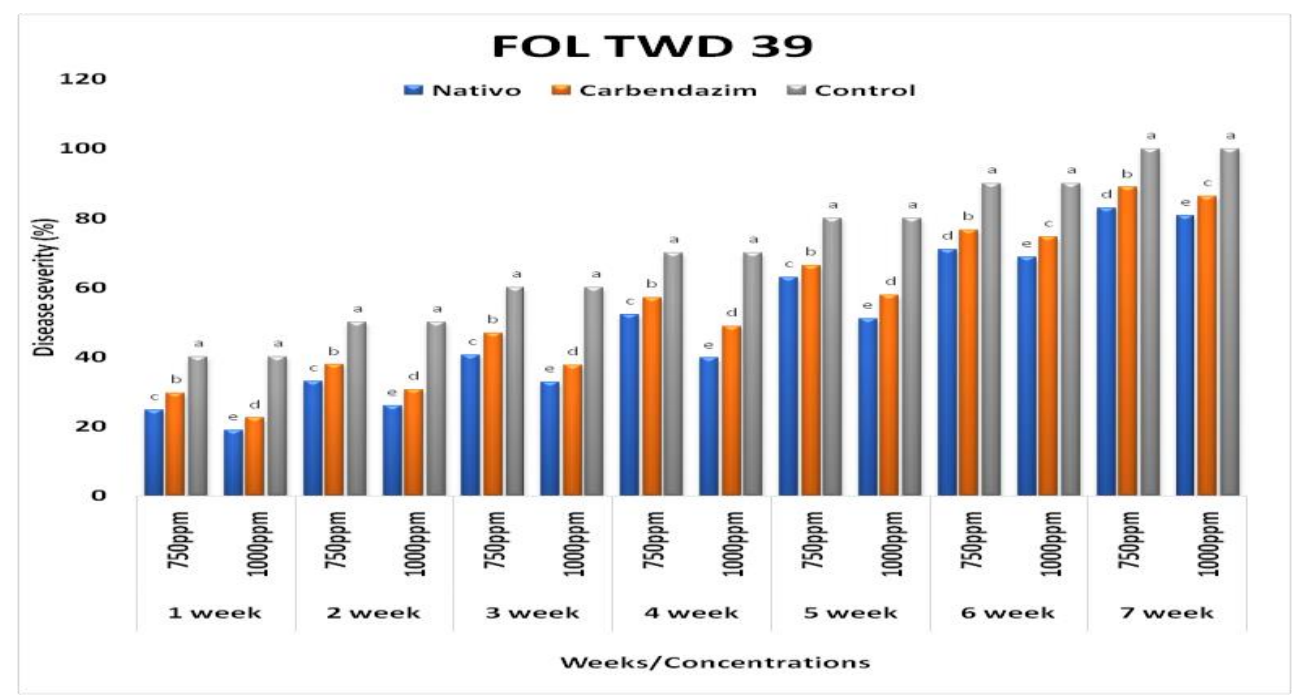

Figure 11. Effect of Nativo and Carbendazim on disease severity of isolate TWD-39 of Fol at 750 and 1000ppm concentrations under greenhouse conditions for the period of seven weeks.

\section{DISCUSSION}

The use of fungicides against the plant pathogen has been believed to be a rapid and potential control measure. A common strategy to mitigate losses due to $F$. oxysporum is to apply synthetic chemical fungicides, particularly those with systemic activity in the host. In vitro trials on PDA, the commercial fungicide Nativo was most effective in suppressing radial growth of $\mathrm{Fol}$, followed by Carbendazim, Benomyl, and Curzate at all three tested rates. These results are in line with the previous studies in which Azoxystrobin, Benomyl, Bromuconazole, Carbendazim, Nativo, and Fludioxonil significantly minimized the growth of Folin vitro (McGovern, 2015). The trials in which plants in the greenhouse were inoculated with different isolates of Fol, Nativo and Carbendazim were the most effective synthetic fungicides. Moreover, Nativo was more effective at both rates that were tested $(750 \& 1000 \mathrm{ppm})$. In previous greenhouse studies, many benzimidazole (prochloraz, propiconazole, thiabendazole, carbendazim, benomyl, thiophanate, and fuberidazole) and triazole (Myclobutanil, triadimefon, difenoconazole, tebuconazole, epoxiconazole) fungicides-controlled tomato wilt to varying degrees (Macías-Sánchez, 2017). Fungicides can boost a crop's genomic capability to produce high yield by lowering disease-related stress. Fungicides which reduce fungal growth have best penetration and therefore arise effective (Ghazanfar et al., 2016) however, yet fungus can acquire resistance against fungicides. Therefore, fungicides must always be administered at proper dosage and intervals (Kirk et al.,
2015). Fungicides are used inadvertently, causing major natural concerns in addition to compromising the wellbeing of users and customers. As a result, choosing appropriate chemicals to manage disease losses is vital.

The application of fungicides can improve the genetic potential of crops and reduce the yield caused by diseases. Protective fungicides inhibit spore germination, but the pathogen can develop resistance to the appliance of fungicides. Therefore, chemicals must be applied repeatedly at appropriate doses and intervals (Krick et al., 2005). Fungal diseases can be controlled using chemicals that suppress or destroy the fungi that cause crop damage. Various compounds were evaluated against the causal organism of tomato wilt disease in these experiments in vitro and under greenhouse conditions. The focus of this research was to find appropriate fungicides to combat the Fusarium wilt disease effectively.

\section{CONCLUSION}

Results of present study demonstrated that Nativo and Carbendazim at 750 and $1000 \mathrm{ppm}$ are effective against Fol both in vitro and under greenhouse conditions. Thus, these fungicides can be recommended to tomato farmers to control tomato wilt disease.

\section{CONFLICT OF INTEREST}

The authors declare that they have no conflicts of interest.

\section{AUTHORS CONTRIBUTIONS}

Dr. Salman Ahmad and Dr. Romana Anjum conceived the 
idea, facilitated, guided and supervised the surveys. Maryam Yousaf executed the field visits, took experimental data. Malik Abdul Rehman and Yasir Ali helped in data analysis. Dr. Waqas Raza re-wrote and finalized the manuscript.

\section{ACKNOWLEDGEMENT}

The authors are thankful to the support provided by Department of Plant Pathology, University of Agriculture, Faisalabad.

\section{REFERENCES}

Ajilogba, C.F. and O.0. Babalola. 2013. Integrated management strategies for tomato Fusarium wilt. Biocontrol science, 18(3): 117-127.

Akrami, M., and Z. Yousefi. 2015. Biological Control of Fusarium wilt of Tomato (Solanum lycopersicum) by Trichoderma spp. as Antagonist Fungi. Biological Forum - An International Journal, 7(1): 887-892.

Alam, T. and G. Goyal. 2007. Packaging and storage of tomato puree and paste. Stewart Postharvest Review, 3(5): 1-8.

Basco, M.J., K. Bisen, C. Keswani and H.B. Singh. 2017. Biological management of Fusarium wilt of tomato using biofortified vermicompost.Mycosphere, 8(3): 467-483.

Bhowmik, D., K.P.S. Kumar, S. Paswan and S. Srivastava. 2012. Tomato-a natural medicine and its health benefits. Journal of Pharmacognosy and Phytochemistry, 1(1): 33-43.

Burgess, L.W., B.A. Summerell, S. Bullock, K.P. Gott and D. Backhouse. 1994. Laboratory Manual for Fusarium Research, 3rd. Edition Dept. of Crop Sciences, University of Sidney.

Chohan, T.Z. and S. Ahmad. 2008. An assessment of tomato production practices in Danna Katchely, Azad Jammu Kashmir. Pakistan Journal of Life and Social Sciences, 6(2): 96-102.

Choi, Y.W., K.D. Hyde and W.H.Ho. 1999. Single spore isolation of fungi. Fungal diversity.

FAOSTAT. 2019. Food and Agriculture Organization of the United Nations, Statistics Division.

Fisher R.A. 1948. Statistical Methods for Research Workers. Oliver and Boyd, London, UK. pp. 354.

Ghazanfar, M.U., W. Raza, K.S. Ahmed, J. Qamar, N. Haider, N and M.H. Rasheed. 2016. Evaluation of different fungicides against Alternaria solani (Ellis \& Martin)
Sorauer cause of early blight of tomato under laboratory conditions. International Journal of Zoology Studies, 1(5): 8-12.

GoP.2018. Economics Survey of Pakistan, 2018-19. https://doi.org/10.5943/mycosphere/8/3/8.

Ignjatov, M., D. Milošević, Z. Nikolić, J. Gvozdanović-Varga, D. Jovičić and G. Zdjelar. 2012. Fusarium oxysporum as causal agent of tomato wilt and fruit rot. Pesticidi I fitomedicina, 27(1): 25-31.

Kirk, W.W., F.M. Abu-El Samen, J.B. Muhinyuza, R. Hammerschmidt, D.S. Douches, C.A. Thill, H. Grozaand A.L. Thompson. 2005. Evaluation of potato late blight management utilizing host plant resistance and reduced rates and frequencies of fungicide applications. Crop Protection, 24(11): 961-970.

Kirk, W.W., F.M. Abu-El Samen, J.B. Muhinyuza, R. Hammerschmidt, D.S. Douches, C.A. Thill, H. Groza and A.L. Thompson. 2005. Evaluation of potato late blight management utilizing host plant resistance and reduced rates and frequencies of fungicide applications. Crop Protection, 24(11): 961-970.

Lievens, B., P.M. Houterman and M. Rep. 2009. Effector gene screening allows unambiguous identification of Fusarium oxysporum f.sp. lycopersici races and discrimination from other formae speciales. Journal of FEMS Microbiology Letters, 300: 201215.

Machado, J.C., D.S. Jaccoud Filho and C.J. Langerak. 2002. Seed-borne fungi: a contribution to routine seed health analysis. International Seed Testing Association.

Macías-Sánchez, K.L. 2017. Fusarium oxysporum f. sp. lycopersici: How can we Control this Fungus? Journal of Advances in Biotechnology and Microbiology, 4(3): 55-56.

Mathur, S.B. and O. Kongsdal. 2003. Common laboratory seed health testing methods for detecting fungi.

McGroven, R.J. 2015. Management of tomato diseases caused by Fusarium oxysporum. International Journal of Crop protection, 73(1): 78-92.

Mj, B., K. Bisen, C. Keswani and S.Hb. 2017. Biological management of Fusarium wilt of tomato using biofortified vermicompost. International Journal of Mycosphere, 8(1): 467-483.

Nirmaladevi, D., M. Venkataramana, R.K. Srivastava, S.R. Uppalapati, V.K. Gupta, T. Yli-Mattila, K.M.C. Tsui, C. Srinivas, S.R. Niranjanaand N.S. Chandra. 2016. 
Molecular phylogeny, pathogenicity and toxigenicity of Fusarium oxysporum f. sp. lycopersici. Scientific reports, 6(1): 1-14.

Nishimura N. 2007. Selective media for Fusarium oxysporum. Journal of Plant Pathology, 73: 342348.

Nizamani, S., A.A. Khaskheli, A.M. Jiskani, S.A. Khaskheli, A.J. Khaskheli, G.B. Poussio, H. Jamroand M.I. Khaskheli. 2020. Isolatation and Identification of the Fungi Causing Tomato Fruit Rot Disease in the Vicinity of Tandojam, Sindh. Agricultural Science Digest, 41: 186-190. doi.10.18805/ag.D-269

Nizamani, S., A.J. Khaskheli, A.A. Khaskheli, A.M. Jiskani, S.A. Khaskheli, G.B. Poussioand M.I. Khaskheli. 2021. The Intensity of Tomato Post-Harvest Rot in the Surroundings of Tandojam. Turkish Journal of Agriculture-Food Science and Technology, 9(2): 288-295.
Patiyal, A., J.P. Mishra and R. Prassad. 2020. In vitro evaluation of fungicides against Fusarium oxysporum f. sp. Wilt of tomato. Journal of Pharmacognosy and Phytochemistry, 9(3): 16701673.

Saeed, A., N. Hassan, A. Shakeel, M.F. Saleem, N.H. Khan, K. Ziaf, R.A.M. Khan and N. Saeed. 2014. Genetic analysis to find suitable parents for development of tomato hybrids. Life Science Journal, 11(12s): 30-35.

Song, W., L. Zhou, C. Yang, X. Cao, L. Zhangand X. Liu. 2004. Tomato Fusarium wilt and its chemical control strategies in a hydroponic system. Crop protection, 23(3): 243-247.

Vincet, J.M. 1947. Distortion of fungal hyphae in presence of certain inhibitors. International Journal of Nature, 159(4051): 850-853.

Publisher's note: EScience Press remains neutral with regard to jurisdictional claims in published maps and institutional affiliations.

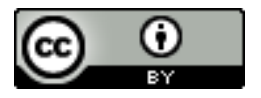

Open Access This article is licensed under a Creative Commons Attribution 4.0 International License, which permits use, sharing, adaptation, distribution and reproduction in any medium or format, as long as you give appropriate credit to the original author(s) and the source, provide a link to the Creative Commons license and indicate if changes were made. The images or other third-party material in this article are included in the article's Creative Commons license, unless indicated otherwise in a credit line to the material. If material is not included in the article's Creative Commons license and your intended use is not permitted by statutory regulation or exceeds the permitted use, you will need to obtain permission directly from the copyright holder. To view a copy of this license, visit http://creativecommons.org/licenses/by/4.0/. 